\title{
Steps of Cutting to Improve Psychomotor Abilities for Early Children, Age Group 4-6 Years
}

\author{
Lukman Hamid \\ Lecturer in Early Childhood Islamic Education \\ Institute of Tarbiyah Science Al-Hidayah Tasikmalaya, Indonesia
}

\begin{abstract}
Psychomotor is a movement that only involves certain body parts that are carried out by small muscles. Therefore, Pshycmotor movements do not really need energy but require careful coordination and accuracy. Psychomotor skills begin to develop after very simple activities such as holding a pencil, holding a spoon, and stirring. Cutting is easy, but if it does not go through the proper steps, the cut results will not be as expected. Scissors is a continuation of the stages of paper tearing activities in early childhood, cutting activities intended to train the child's Pshycomotorics, especially training the child's fingers with paper media and knobs with certain stages and patterns.
\end{abstract}

Keywords: Cutting is Part of The Pshycomotoric Stages of Early Childhood

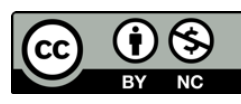

This is an open access article under the CC-BY-NC license.

\section{INTRODUCTION}

In order to increase the learning awareness of the Indonesian people, the government implements children's education from an early age so that children can continue their education to a higher level with the provisions and abilities that have been prepared. Of course, this will relate to the preparation before learning; including the media, the stages of learning, and the goals to be achieved.

Cutting is one activity that supports psychomotor development (cutting is a series of activities after tearing and kneading). Cutting plays an important role in the learning process; the goal is to train children's concentration and accuracy. Cutting can be used as a tool to bring the teacher's perceptions and understanding closer to the child's grasping power. With the cutting stage, children will be more enthusiastic about playing while learning, increasing their motor-sensory abilities, developing their finger muscles, and developing their hand muscles. The benefit of cutting is that students can coordinate lines and fingers by following a straight-line pattern. Also, students will be perfect in holding scissors. Besides that, children will learn to control emotions, and children can play while learning (Crain W in Mahmuda, 2015, p.7).

Cutting is an activity that involves and requires coordination between eyes, hands, and concentration (Chabibah, 2005, p. 1). From the description above, it can be concluded that cutting is a skill to operate a scissors tool to cut an object - all forms of communication tools that can be used to convey messages/information from sources to students which aim to stimulate the thoughts, feelings, interests, and attention of students to participate in learning activities.

Early Childhood Education is one of the strategic policies in human resource development considering that (1) this early age is the golden age, (2) the growth and development of children at an early age greatly determine the degree of health quality, intelligence, and maturity, emotional and human productivity at a later stage (Muhammad, 2012, p. 1). 
Table 1. The Steps of Cutting in Early Children

\begin{tabular}{|c|c|c|c|}
\hline No & Tools and Materials & Steps & Description \\
\hline 1. & $\begin{array}{l}\text { - Small scissors (adjust to the } \\
\text { child's developmental age) } \\
\text { - Paper (can use used paper } \\
\text { (newspaper, consumable } \\
\text { paper, and others), Hvs } \\
\text { paper, or folding paper. }\end{array}$ & Step 1 & $\begin{array}{l}\text { The child cuts the edges of the } \\
\text { paper with the tip of the scissors } \\
\text { as a whole. Then stick it in a } \\
\text { picture book or special } \\
\text { attachment book, with the aim of } \\
\text { the child archiving all of his } \\
\text { activities. }\end{array}$ \\
\hline 2. & & Step 2 & $\begin{array}{l}\text { The child cuts the edges of the } \\
\text { paper by opening the scissors } \\
\text { completely and closing them } \\
\text { again so that they form a one- } \\
\text { piece pattern on the entire } \\
\text { surface of the paper. }\end{array}$ \\
\hline 3. & & Step 3 & $\begin{array}{l}\text { The children cut precisely in the } \\
\text { vertical straight line pattern that } \\
\text { the teacher has drawn on the } \\
\text { paper, and the children cut } \\
\text { according to the pattern that the } \\
\text { teacher has provided. }\end{array}$ \\
\hline 4. & & Ste & $\begin{array}{l}\text { The child cuts between the two } \\
\text { vertical straight lines that the } \\
\text { teacher has drawn on the paper, } \\
\text { and the child cuts according to } \\
\text { the pattern that the teacher has } \\
\text { provided. }\end{array}$ \\
\hline 5. & & 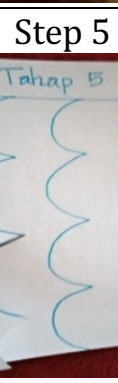 & $\begin{array}{l}\text { The child cuts a left curved } \\
\text { pattern that resembles a wave } \\
\text { that the teacher has drawn on } \\
\text { the paper, and the child cuts } \\
\text { according to the pattern that the } \\
\text { teacher has provided. }\end{array}$ \\
\hline
\end{tabular}




\begin{tabular}{|c|c|c|}
\hline 6. & Step 6 & $\begin{array}{l}\text { The child cuts a right-curved } \\
\text { pattern that resembles a wave } \\
\text { that the teacher has drawn on } \\
\text { the paper, and the child cuts } \\
\text { according to the pattern that the } \\
\text { teacher has provided. }\end{array}$ \\
\hline 7. & Step 7 & $\begin{array}{l}\text { The children cut out the wave } \\
\text { patterns that the teacher has } \\
\text { drawn on the paper, cut } \\
\text { according to the pattern that the } \\
\text { teacher has provided. }\end{array}$ \\
\hline 8. & Step 8 & $\begin{array}{l}\text { The children cut the zigzag } \\
\text { pattern that the teacher has } \\
\text { drawn on the paper, cut } \\
\text { according to the pattern the } \\
\text { teacher has provided }\end{array}$ \\
\hline 9. & Step 9 & $\begin{array}{l}\text { The child cuts a triangle shape } \\
\text { right on the line that the teacher } \\
\text { has drawn on the paper, cuts } \\
\text { according to the pattern that the } \\
\text { teacher has provided }\end{array}$ \\
\hline 10. & Step 10 & $\begin{array}{l}\text { The child cuts a triangle outside } \\
\text { the line that the teacher has } \\
\text { drawn on the paper, and the } \\
\text { child cuts according to the } \\
\text { pattern that the teacher has } \\
\text { provided }\end{array}$ \\
\hline 11. & Step 11 & $\begin{array}{l}\text { The child cuts a rectangle right } \\
\text { on the line that the teacher has } \\
\text { drawn on the paper, and the } \\
\text { child cuts according to the } \\
\text { pattern that the teacher has } \\
\text { provided }\end{array}$ \\
\hline
\end{tabular}




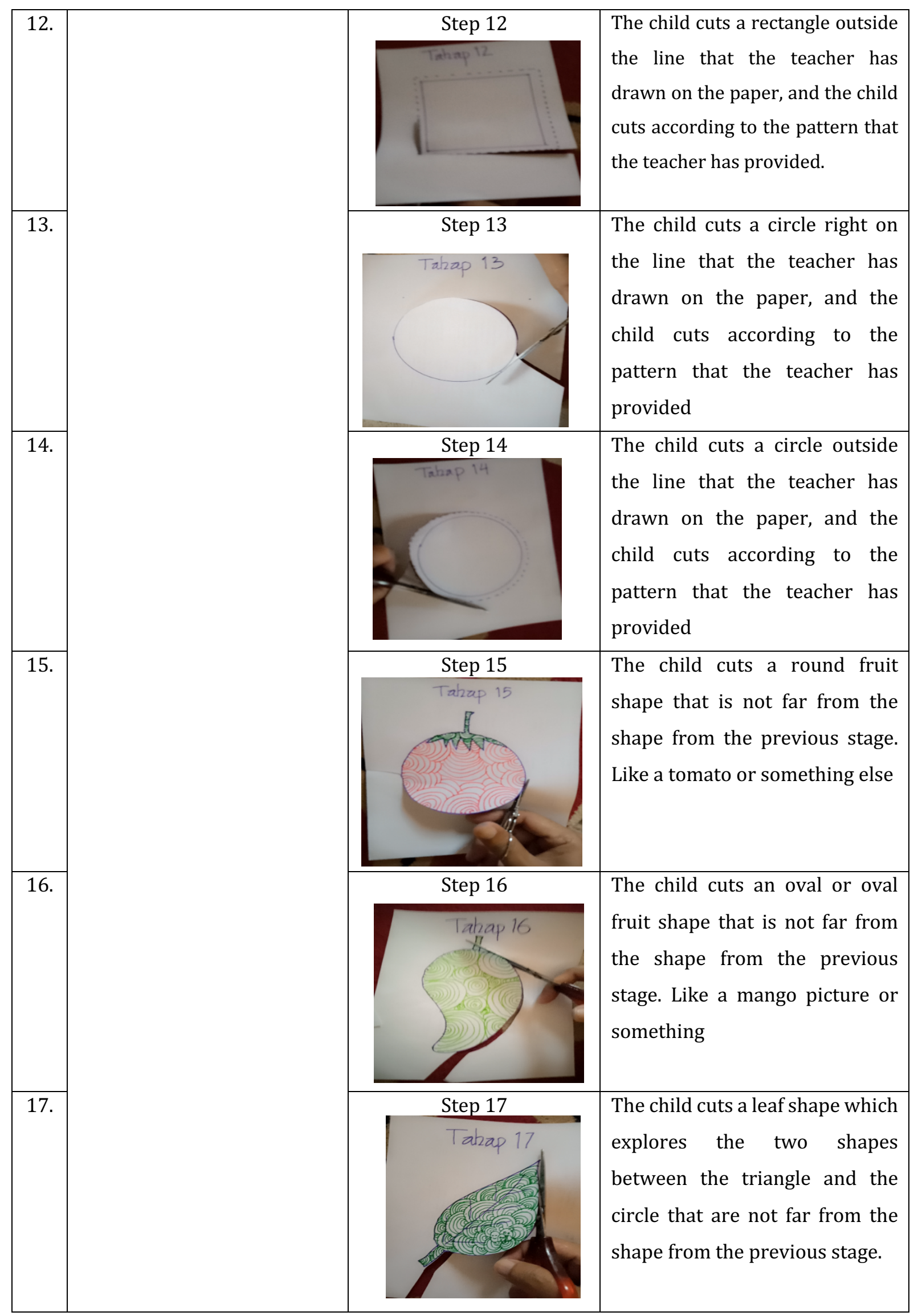


International Journal of Emerging Issues in Early Childhood Education (IJEIECE) Vol. 3 (2), 01-09

Steps of Cutting to Improve Psychomotor Abilities for Early Children, Age Group 4-6 Years

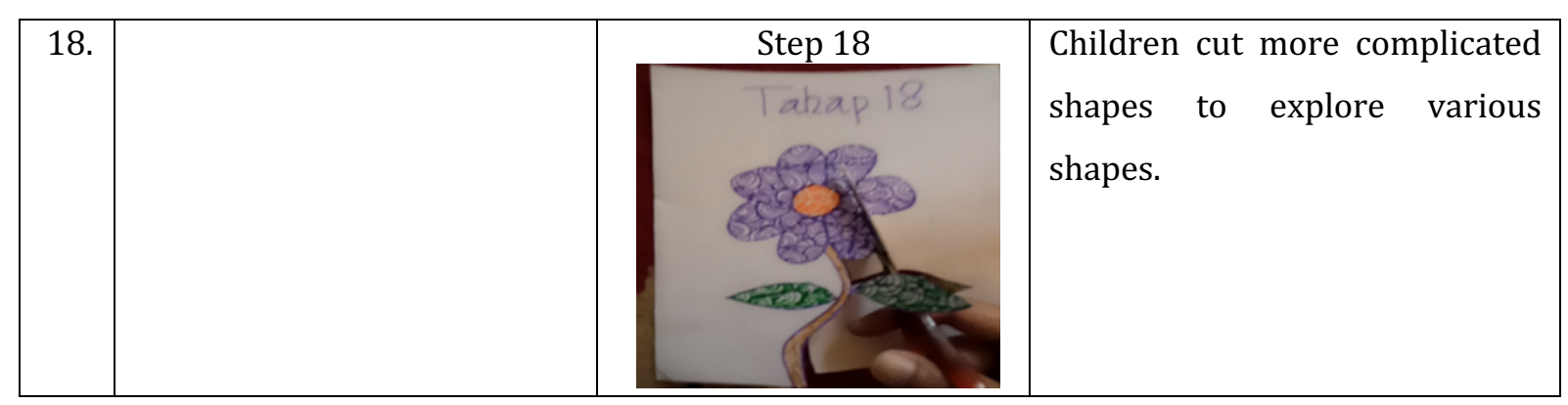

Children's motor skills are obtained by the child always trying to move physically in a controlled and directed manner in accordance with the general rules of cutting procedures. The ability is obtained from repeated hand exercises so that the longer the child will be able to control and direct so that what is produced from their hands is completed with what they want. From this habit, work skills will be achieved. From the description above, the researcher concludes that psychomotor skills, that is, teachers need to provide examples of the stages well, and it is suggested that teachers do more frequent pattern cutting activities so that children's psychomotor skills are more stimulated.

\section{RESEARCH METHODS}

This research is a qualitative descriptive study. In this paper, analysis documents are used as one of the techniques for collecting data through written and electronic documents from four studies. The analysis document that the author uses in this study is the RPPH (Daily Learning Implementation Plan) made by the teacher concerned. The instrument in this study was an observation sheet (checklist).

\section{FINDING AND DISCUSSION}

Regarding descriptive data analysis, this section will describe the results of observations and interviews from the teacher's efforts in developing children's psychomotor skills through cutting pattern activities in group A at Kindergarten At-Taqwa Jl. Merdeka Belakang 69 Tarogong Kidul District Garut Regency, they are 1) The teacher prepares a picture according to the theme; 2) The teacher prepares the tools and equipment for cutting activities; the teacher prepares pattern-cutting activity equipment to make it easier for students to carry out activities; 3) The teacher provides directions from beginning to end during cutting pattern activities in developing children's psychomotor skills; 4) The teacher observes and corrects some children who are less able to cut paper properly; there are still many children who do not use scissors properly so students need the help of the teacher; 5) The teacher provides an assessment of the results of student work after the activity ends; The teacher determines the results of the pattern-cutting activity assessment using a checklist that matches the cutting activity indicator.

In the process of developing children's psychomotoric activities through cutting pattern activities, the teacher has carried out several stages, including preparing images according to the theme in patterncutting activities in developing children's psychomotor skills. Therefore, preparing a theme in patterncutting activities is very important in order to make it easier for children to build a concept about an object or event in the implementation of the process of psychomotor development activities. Furthermore, in psychomotoric development through cutting patterns, after the teacher prepares pictures according to the theme, then the teacher prepares the tools for cutting activities. Namely, the teacher prepares scissors, glue, and pictorial magazines that the children will cut according to the number of children.

The results of observations made by researchers are in line with the results obtained by previous experts if the interesting tools and materials used by children increase their motivation. The teacher prepares interesting tools or materials and provides direction to students during pattern-cutting activities in developing children's psychomotor skills. 
The teacher is a facilitator for students in activities; then the teacher explains how to cut correctly to students from beginning to end in order to make it easier for students to do pattern-cutting activities in developing psychomotor skills. Agree with Polina Resty that teachers play a role in teaching children; teachers act as facilitators who provide opportunities for children to express their experiences.

The success of a child depends on the readiness of a teacher. The teacher explains how to hold the scissors properly and correctly first to the students; then the teacher explains the stages of cutting, starting from cutting the edges of the image to follow the shape of the picture pattern. The teacher not only provides guidance on cutting activities but the teacher also observes and corrects some children who are less able to cut paper properly. After the teacher has finished explaining how to cut properly, then the teacher distributes a patterned picture magazine that the students will cut.

It can be seen from the pattern-cutting activity; there are some children whose psychomotor development is still underdeveloped. The child cannot hold the scissors properly and correctly, so they need the teacher's help to complete the pattern-cutting activity. The teacher not only exemplifies how to cut properly and correctly, but the teacher also has to assess the results of implementing patterncutting activities in developing psychomotor skills carried out by children because each individual has different abilities. So that giving an assessment by the teacher on the results of the implementation of pattern-cutting activities carried out by children in psychomotoric development is very important to do. According to Hansen, Kirstine, one of the real forms of seeing children's differences is by examining the child's achievement because the level of ignition of each children's ability is different.

\section{CONCLUSIONS AND SUGGESTIONS CONCLUSION}

Based on the analysis results and previous discussion, the researchers concluded that the teacher's efforts in developing children's psychomotor skills through pattern-cutting activities at Kindergarten At-Taqwa Jl. Merdekaakang 69 Tarogong Kidul District Garut Regency. The activities are (1) The teacher prepares pictures according to the theme (sets the theme by analyzing the 2013 curriculum syllabus), (2) The teacher prepares tools for cutting activities such as scissors, pictorial magazines with patterns and glue, (3) The teacher provides directions during pattern-cutting activities in developing psychomotor skills of children; after the teacher prepares the tools and materials, then the teacher explains how to cut properly and correctly, (4) The teacher explains how to hold the scissors correctly, the teacher explains how to cut a patterned picture correctly, so it doesn't cross the pattern, and the teacher explains how to glue and stick pictures correctly, (5) The teacher observes to improve some children who are less able to cut paper properly; after the teacher give directions, then the teacher correct some children who are less able to cut properly and correctly. The teacher supervises and corrects children who are less able to cut properly, (6) The teacher provides an assessment of the results of student work.

\section{SUGGESTION}

Based on the conclusions of the research and discussion results, the researcher suggests (1) for the school to achieve optimal learning objectives, the teacher should be more creative and innovative in presenting material in class so that children are motivated to take part in learning activities, and (2) for teachers. It is better to use good learning strategies and motivation toward children so that learning becomes more effective and fun and children do not feel bored quickly, especially for the aspects of psychomotor skills. 


\section{REFERENCES}

Aguilar-Alaníz, M.L.; Rolón-Lacarriere, O.G.; Cervantes, A. Effectiveness of the program to psychomotor postural equilibrium in spastic hemiparesis children with level of motor cortical development in children's. Rev. Mex. Neuroc. Mex. 2010, 11, 269-278.

Ajuriaguerra, J. Manual de Psiquiatría Infantil; Massón: Barcelona, España, 1983.

Aliaga, L.; Figueroa, T. Educación: Pilar fundamental de la educación. Revista Educrea 2018, 1, 1-2. Vericat, A.; Orden, A.B. Herramientas de Screening del Desarrollo Psicomotor en Latinoamérica. Rev. Chilena Pediátr. 2010, 81, 391-401.

Arrese, H. La Psicomotricidad Fina y el Desarrollo de la Escritura en Los Estudiantes de Cinco Años de Educación Infantil. Ph.D. Thesis, Universidad Cesar Vallejo, Chiclayo, Perú, 2019.

Aucoutier, B.; Lapierre, A. La Educación Psicomotriz Como Terapia, "Bruno"; La Médica y técnica: La Habana, Cuba, 1985.

Berruezo, P.P. El cuerpo, el desarrollo y la Psicomotricidad. Psicomotricidad Rev. Estud. Exp. 1995, 49, $15-26$.

Berruezo, P.P. Hacia un marco conceptual de la Psicomotricidad a partir del desarrollo de su práctica en Europa y en España. Rev. Int. Form. Prof. 2000, 37, 21-33.

Bolaños-Motta, J.I.; Pérez-Rodríguez, M.A.; Casallas-Forero, E. Alfabetización Corporal. Una propuesta de aula desde la psicomotricidad. Estudios Pedagógicos 2018, 44, 23-34.

Brigada, A.C. Psicomotricidad Vivencial y Lenguaje Oral en Niños de Cinco Años de Una Institución Educativa Publica de Ventanilla-Callao. Ph.D. Thesis, Universidad San Ignacio de Loyola, Lima, Perú, 2019.

Bustos, E.; Castellani, M.N. Una mirada desde la complejidad de una niña, el aporte psicomotriz en la interdisciplinariedad. Un caso clínico: "Agustina". Revista Iberoamericana Psicomotricidad Técnicas Corporales 2018, 43, 97-110.

Campos de Sousa, D. Psychopedagogical proposal to develop psychomotor skills in children of early childhood education. Ibero Am. J. Psychomot. Body Tech. 2003, 12, 61-82.

Cañizares, J.M.; Carbonero, C. El Crecimiento y el Desarrollo Neuromotor, Óseo y Muscular en la Edad Escolar; Wanceulen: Sevilla, España, 2016.

Cecchini, J.A.; Fernández, J.L.; Pallasá, M.; Cecchini, C. El proceso de transferencia en el aprendizaje y el desarrollo motor. Rev. Psicothema 2012, 24, 205-210.

Chabibah, W. (2005). Peningkatan Motorik Halus Anak Usia 3-4 Tahun Melalui Menggunting Dasar Di Sps Al-Mutaqqin Jombang.

Cipollone, M.D. La dislexia, desde el cuerpo. Revista Iberoamericana Psicomotricidad Técnicas Corporales 2018, 43, 126-137.

Cobos, P. El Desarrollo Psicomotor y Sus Alteraciones: Manual Práctico Para Evaluarlo y Favorecerlo; Pirámide: Madrid, España, 2007.

Comellas, M.J.; Perpinyà, A. Psicomotricidad en la Educación Infantil. Recursos Pedagógicos; CEAC: Barcelona, España, 2003.

Da Fonseca, V. Ontogénesis de la Motricidad: Estudio Psicobiológico del Desarrollo Humano; G. Núñez Editor: Madrid, España, 1988.

Defontaine, J. Manual de Reeducación Psicomotriz. Diploma de Psicoreeducador del Estado Francés; Médico y Técnica: Barcelona, España, 1978.

Delgado-Lobete, L.; Montes, R. Perfil y desarrollo psicomotor de los niños españoles de 3 a 6 años. Sport. Rev. Técn. Cient. Deport. Esc. Educ. Fís. Psicomot. 2017, 3, 454-470.

Ferry-Rey, G.; Dueñas, J.M.; Camps, C. Diferencias entre psicomotricidad dinámica y normativa en el desarrollo infantil. Rev. Int. Med. Científica Act. Física Deporte. in press.

Flamant, C.; Branger, B. Parent completed development screening in prematura children: A valid tool for follow up programs. PLoS ONE 2011, 6, e20004.

Gessell, A. Diagnostico del Desarrollo Normal y Anormal del Niño; Paidos: Buenos Aires, Argentina, 1981. Piaget, J. El Nacimiento de la Inteligencia en el Niño; Aguilar: Madrid, España, 1969. 
International Journal of Emerging Issues in Early Childhood Education (IJEIECE) Vol. 3 (2), 01-09

Steps of Cutting to Improve Psychomotor Abilities for Early Children, Age Group 4-6 Years

Gessell, A. El Infante y el Niño En La Cultura Actual; Paidós: Buenos Aires, Argentina, 1979.

Herón-Flores, M.; Gil-Madrona, P.; Sáez-Sánchez, M.B. Contribución de la terapia psicomotriz al progreso de niños con discapacidades. Rev. Fac. Med. 2018, 66, 75-81.

Lagrange, G. Educación Psicomotriz. Guía Práctica Para Niños de 4 a 14 Años. Educación Didáctica; Martínez Roca: Madrid, España, 1986.

Le Boulch, J. Desarrollo Psicomotriz Desde el Nacimiento Hasta Los 6 Años. Practica de la Psicomotricidad en la Escuela Preescolar: Consecuencias Educativas; Paidós: Buenos Aires, Argentina, 1962.

Lesma, M.L.; Pérez-González, B.; Salinero, J.J. Relative age effect (RAE) in spanish football leage. J. Sport Health Res. 2011, 3, 35-46.

Ley Orgánica 39/2006, de 14 de Diciembre de Promoción de Autonomia Personal y Atención a Las Personas en Situación de Dependencia; BOE num.299; Boletin Oficial del Estado: Madrid, Spain, 2006; pp. 44142-44156.

Limbos, M.M.; Joyce, D.P. Comparison of the ASQ and PEDS in screening for developmental delay in children presenting for primary care. J. Dev. Behav. Pediatr. 2011, 32, 499-511.

Mahmuda. (2015) Mengembangkan Motorik Halus Melalui Kegiatan Menggunting Kertas Mengikuti Pola Garis Lurus pada Anak Usia 3-4 Tahun, Universitas Nusantara PGRI Kediri.

McCathy, D. Escalas McCarthy de Aptitudes y Psicomotricidad Para Niños; Pearson SA: Madrid, España, 2011. Santana, A.C.; Rojas, M.; Pacheco, J.S. McCarthy scales of skills and psychomotor skills for children. Adv. Meas. 2006, 4, 148-149.

Mendieta, L.; Gayrey, O.; Valverde, M.X.; Vargas, J.D. Incidencia en el juego de la rayuela en el desarrollo de la psicomotricidad. Rev. Multidiscip. Investig. Cient. Espirales 2019, 3, 1-17.

Minujín, A.; Bagnoli, V.; Osorio, A.M.; Aguado, L.F. Primera Infancia Cómo Vamos: Identificando Desigualdades

Monge, M.Á.; Meneses, M. Instrumentos de evaluación del desarrollo motor. Rev. Educ. 2002, 26, 155168.

Mora, J.; Palacios, J. Desarrollo Físico y Psicomotor a lo Largo de los Años Preescolares. Psicología del Desarrollo; Félix Valera: La Habana, Cuba, 1991.

Muhammad, H. (2012). Pedoman Penyelenggaraan PAUD Terpadu. Jakarata: Dirjen Pembinaan PUD

Noguera, L.M.; Quintero, M.V.; García, R.; Viderte, J.A. Efectos de un programa de ejercicios sobre perfil psicomotor en escolares. Revista Colomb. Rehabil. 2015, 14, 38-44.

Para Impulsar la Equidad en la Infancia Colombiana; Sello Editorial Javeriano: Santiago de Cali, Colombia, 2015.

Picq, L.; Vayer, P. Educación Psicomotriz y Retraso Mental; Científico-Médico: Barcelona, España, 1969.

Portellano, J.A.; Martínez-Arias, R.; Zumarraga, L. ENFEN, Evaluación Neuropsicológica de Las Funciones Ejecutivas en Niños; TEA: Madrid, España, 2009.

Rabadán, M.; Serranoba, J. El abordaje psicomotriz en niños con autismo. Rev. Eipea 2017, 2, 1-14. Chipana, A.R.; Ordoñez, C.M. Nivel de Psicomotricidad de Los Niños y Niñas de Cinco Años de la I.E.I

Rodríguez-Camacho, D.F.; Alvis-Gomez, K.M. Generalidades de la imagen corporal y sus implicaciones en el deporte. Rev. Fac. Med. 2015, 63, 279-287.

Schonhaut, L. Evaluación del desarrollo Psicomotor en las consultas pediátricas. Experiencia en clínica alemana. Rev. Contacto Cient. 2010, 31, 455-466.

Schonhaut, L.; Álvarez, J.; Salinas, P. El pediatra y la evaluación del desarrollo psicomotor. Rev. Chilena Pediatr. 2008, 79, 26-31.

Schonhaut, L.; Armijo, I. Aplicabilidad del Ages y Stages Questionnaires para el tamizaje del desarrollo psicomotor. Rev. Chilena Pediatr. 2014, 85, 12-21.

Schonhaut, L.; Salinas, P.; Armijo, I.; Schönstedt, M.; Álvarez, J.; Manríquez, M. Validación de un cuestionario Administrado para Evaluación del desarrollo Psicomotor. Rev. Chilena Pediatr. 2009, 80, 513-519. 
International Journal of Emerging Issues in Early Childhood Education (IJEIECE) Vol. 3 (2), 01-09

Steps of Cutting to Improve Psychomotor Abilities for Early Children, Age Group 4-6 Years

Rostika Srihilmawati

Terry, J. Análisis de la Influencia de la Metodología de la Intervención Psicomotriz Sobre el Desarrollo de Las Habilidades Motrices en Niños de 3 a 4 Años. Ph.D. Thesis, Universidad de Murcia, Murcia, España, 2014.

Tierney, L.; Smith, L.; Axworthy, D.G.; Radeliffe, S.G. The Mc Carthy Scales of childrens Abiloties sex and handedsness effects in 128 scotish five years old. Br. J. Educ. Psychol. 1984, 54, 101-105.

Vega, A. Lateralidad, Organización y Estructuración Espacial en Niños Con Dificultades; Trabajo fin de Grado; Universidad de La Rioja: Logroño, España, 2017.

Wallon, H. La Evolución Psicológica del Niño; Critica: Barcelona, España, 2000. 